\title{
Amphibians of the Parque Nacional da Restinga de Jurubatiba, a sandy coastal environment in southeastern Brazil
}

\author{
Luiz Fernando Carmo ${ }^{1,2} * \mathbb{E}^{\mathbb{E}}$, Ingrid Ribeiro Miguel ${ }^{1,3}$, Pedro H. Pinna ${ }^{1,2}$, Daniel Silva Fernandes ${ }^{1,2}$ \& \\ Manoela Woitovicz-Cardoso \\ ${ }^{1}$ Universidade Federal do Rio de Janeiro, Museu Nacional, Departamento de Vertebrados, Setor de \\ Herpetologia, Quinta da Boa Vista, 20940-040, Rio de Janeiro, RJ, Brasil \\ ${ }^{2}$ Universidade Federal do Rio de Janeiro, Instituto de Biologia, Departamento de Zoologia, Ilha do Fundão, \\ 21941-902, Rio de Janeiro, RJ, Brasil \\ ${ }^{3}$ Universidade Federal do Rio de Janeiro, Campus Macaé, Núcleo em Ecologia e Desenvolvimento \\ Socioambiental de Macaé, 27965-045, Barreto, Macaé, RJ, Brasil \\ *Corresponding author: Luiz Fernando Carmo,e-mail: luiz.carmo@ufrj.br
}

CARMO L. F., MIGUEL I. R., PINNA P. H., FERNANDES D. S., WOITOVICZ-CARDOSO M. Amphibians of the Parque Nacional da Restinga de Jurubatiba, a sandy coastal environment in southeastern Brazil. Biota Neotropica. 19(2): e20190727. http://dx.doi.org/10.1590/1676-0611-BN-2019-0727

\begin{abstract}
We provide an inventory checklist of the amphibians from Parque Nacional da Restinga de Jurubatiba (PNRJ), a sandy coastal environment in southeastern Brazil. As a result of three years of surveys, from August 2013 to June 2016, a total of 36 amphibians species were recorded - one Gymnophiona (Typhlonectidae) and 35 species of five anuran families: Bufonidae (2 species), Craugastoridae (1), Hylidae (21), Leptodactylidae (8), and Microhylidae (3). One specie is reported for the first time for the restinga ecosystem (Chthonerpeton braestrupi) and 24 species were recorded for the first time to the PNRJ. This result reinforces the importance of long-term studies for accurate knowledge of the biodiversity. Considering that the biodiversity of the fragments of the sandy coastal environments in the state of Rio de Janeiro is poorly known, the present study provided a more detailed knowledge about different aspects of the biodiversity in the PNRJ, contributing to the preservation of this threatened ecosystem. Keywords: Herpetology, Anura, Inventory, Species Richness, Rio de Janeiro, Conservation.
\end{abstract}

\section{Anfíbios do Parque Nacional da Restinga de Jurubatiba, um ambiente costeiro no sudeste do Brasil}

Resumo: Nós fornecemos um inventário dos anfíbios do Parque Nacional da Restinga de Jurubatiba (PNRJ), uma zona costeira de ambiente arenoso no sudeste do Brasil. Como resultado de três anos de pesquisas, no período de Agosto de 2013 a Junho de 2016, foram registradas um total de 36 espécies de anfíbios - uma Gymnophiona (Typhlonectidae) e 35 espécies de cinco famílias de anuros: Bufonidae (2 espécies), Craugastoridae (1), Hylidae (21), Leptodactylidae (8) e Microhylidae (3). Uma espécie é registrada pela primeira vez para o ecossistema de restinga (Chthonerpeton braestrupi) e 24 espécies foram registradas pela primeira vez para o PNRJ. Este resultado reforça a importância de estudos de longo prazo para um conhecimento preciso da biodiversidade. Considerando que a biodiversidade dos fragmentos dos ambientes costeiros no estado do Rio de Janeiro é pouco conhecida, o presente estudo proporcionou um conhecimento mais detalhado sobre os diferentes aspectos da biodiversidade no PNRJ, contribuindo para a preservação desse ecossistema ameaçado.

Palavras-chave: Herpetologia, Anura, Inventário, Riqueza de Espécies, Rio de Janeiro, Conservação. 


\section{Introduction}

Brazil has the greatest amphibian richness in the world, with about 1080 species distributed in 25 families (Segalla et al. 2016; Frost, 2018). The morphoclimatic domain of the Atlantic Forest is known as a conservation hotspot due to its high concentration and maintenance of biodiversity (Myers et al. 2000), comprising about 540 species, of which $88 \%$ are endemic to this ecosystem (Haddad et al. 2013). This remarkable richness is related to the diversity of microenvironments found in the biome, which possibly contributes to the evolution of various reproductive modes and speciation events (Haddad \& Prado 2005; Vasconcelos et al. 2010).

Originally, the Atlantic Forest extended over nearly the entire coastline of Brazil, displaying different vegetation landscapes throughout its distribution (Falkenberg 1999). One of the habitats observed in this biome are the restingas, dating from the Quaternary, and whose seasonal dynamic and morpho-physiological composition is mostly shared with other ecosystems, such as Tabuleiros and Caatingas (Freire 1990). Restingas extend over about $79 \%$ of the coast (Lacerda et al. 1993), being one of the most extensive ecosystems in Brazil and having multiple fragmented areas along its distribution (Teixeira et al. 2002). The flora is adapted to withstand extreme environmental conditions, such as sandy substrate with high salt concentration, high exposure to sunlight and low water potential (Henriques et al. 1986; Assumpção \& Nascimento 2000; Scarano 2002). Bromeliads are very common and widely distributed in this environment (Cogliatti-Carvalho et al. 2001), being an essential element especially for amphibians (Teixeira et al. 2002). They provide a significant amount of rainwater in their central tube, serving as sites for foraging, breeding and protection against possible predators (Peixoto 1995; Schineider \& Teixeira 2001).

Despite the great extension of the Brazilian coastline, the coastal ecosystems are the most anthropically impacted (directly and indirectly), mostly due to the unequal and unrestrained occupation of the country initiated in the 16th century, from the sea towards inner lands (Dean 1997; Tabarelli et al. 2010). In addition to the loss of natural habitats, another issue concerning the conservation of amphibians in the Atlantic Forest is that recent studies estimate the decline of populations in the coming years, largely due to global climatic changes and the contamination by the fungus Batrachochytrium dendrobatidis (Fisher et al. 2012; Loyola et al. 2014; Jenkinson et al. 2016). Some studies related to amphibians assemblage in restingas have been carried out in the last years in order to provide a more detailed inventory of their composition (e.g. Bastazini et al. 2007; Rocha et al. 2008; Narvaes et al. 2009, Wachlevski \& Rocha 2010; Vilela et al. 2011; Telles et al. 2012; Oliveira \& Rocha 2015; Gondim-Silva et al. 2016; Oliveira et al. 2017).

The Parque Nacional da Restinga de Jurubatiba (PNRJ) was created on April 29, 1998 with the main purpose of protecting and preserving one of the most threatened ecosystems of the country since the colonial period (Esteves \& Lacerda 2000). Currently, despite being a federal conservation unit, the PNRJ is still under strong anthropic pressure (Rocha et al. 2007). The taxocenosis of amphibians from the PNRJ was previously studied by Van Sluys et al. (2004). Herein we provide an updated checklist of amphibians for the PNRJ.

\section{Material and Methods}

\section{Study site}

The present study was carried out in the Parque Nacional da Restinga de Jurubatiba (22 $2^{\circ} 16^{\prime} \mathrm{S}, 41^{\circ} 39^{\prime} \mathrm{W}$ ) located on northern state of Rio de Janeiro, southeastern Brazil (Fig. 1). It is one of the largest remnants of restinga in Brazil with 14,992 hectares, extending through the municipalities of Macaé, Carapebus, and Quissamã. It is the only fragment of restinga in the country to be titled as national park (Brasil 2016). As in most of the restingas found in Brazil, the vegetation is composed of a mosaic of forested and open areas.

The study was carried out in the municipality of Carapebus, in three distinct zones of the PNRJ. These zones were selected and classified based on phytophysiognomic characteristics as follow: Clusia spp. open formation; dry forest of restinga; and an intermediate zone between these two formations (Fig. 2). The Clusia spp. open formation is closer to seashore and was defined by Araújo et al. (1998) as "shrub vegetation of Clusia" (SVC). It was characterized as having more sparse vegetation, separated by strips of bare sand, with high solar incidence and low potential of fresh water. The zone here classified as an intermediate area also had its physiognomy defined by Araújo et al. (1998), who called it "open shrub of Ericaceae" (OSE). This region shows fragments of irregular vegetation varying from shrubs to trees. It is located between the Clusia spp. open formation and the dry forest of restinga. The third zone, dry forest of restinga (DFR), corresponds to an area with vegetation more densely distributed. In this area, one can find large trees and a large ammount of decomposing plant material, forming a dense litter. The availability of water is larger compared to the other zones, with temporary swamps and periodically flooded areas (pers. obs).

\section{Field methods and data analyses}

Fieldwork consisted of quarterly surveys over three years, from August 2013 to June 2016, in a total of 12 surveys lasting seven days each. We applied two methods for sampling amphibians: pitfall traps (according to the standard procedures of Cechin \& Martins 2000) and Complete Species Inventory (sensu Scott Jr. 2001). These methods were chosen as they are the most effective for accessing anuran taxocenosis in restingas (Rocha et al. 2004a). Twenty one pitfall traps arrays were used, each one with four $60 \mathrm{~L}$ buckets. Seven arrays were placed in each of the three zones previously determined (Fig. 1). Nineteen pitfall arrays were Y-shaped (one central bucket linked to other three peripherals forming angles of approximately $120^{\circ}$ ), and two pitfall arrays were linked in one straight line with eight buckets. Buckets of each pitfall array were connected by $4-5 \mathrm{~m}$ long and $0.5-1 \mathrm{~m}$ high drift fences. Each pitfall array was sampled once along the consecutive days of each survey, corresponding to a total sample effort of 7,056 bucket nights. Regarding the Complete Species Inventory, eight sampling areas were selected and sampled in all surveys (Periodically sampled areas). Two of these correspond to areas of "dry forest of restinga", four are located in "Clusia spp. open formations", and two in areas of "open shrub of Ericaceae" (Fig. 1). We occasionally performed Complete Species Inventory on another twenty-six areas (extra sample areas) in order to maximize sampling (Fig. 1). Everyday nocturnal Complete Species Inventory was performed by three to five researchers, during two 

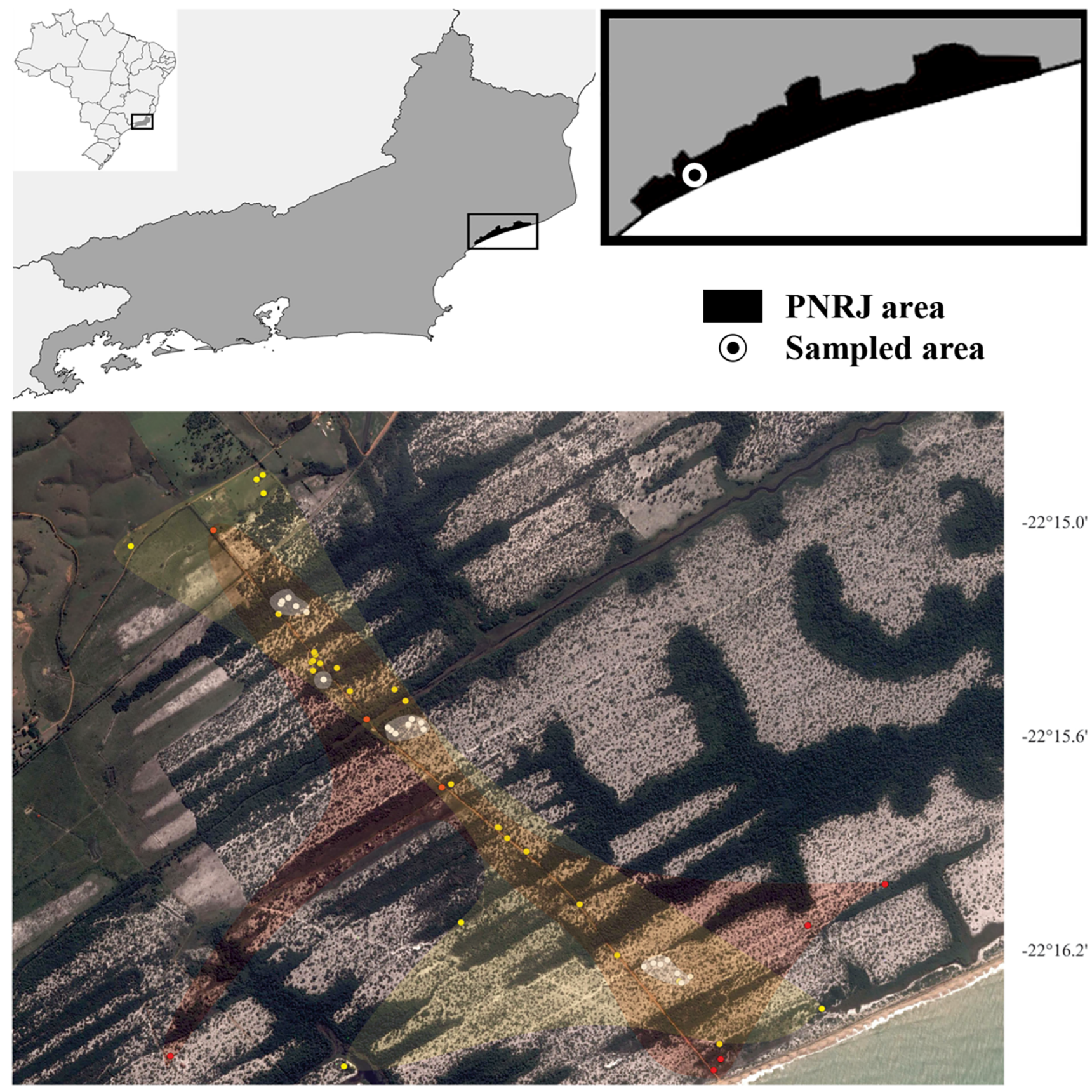

$-41^{\circ} 40.2^{\prime}$

$-41^{\circ} 39.6^{\prime}$

$-41^{\circ} 39.0^{\prime}$

$-41^{\circ} 38.4^{\prime}$

Figure 1. Localization of Parque Nacional da Restinga de Jurubatiba (PNRJ) in the state of Rio de Janeiro, southeastern Brazil. Sampling areas are indicated by: White circles $=$ Pitfall traps; Red circles $=$ Periodically sampled areas of Complete Species Inventory; Yellow circles $=$ Extra sample areas, occasionaly sampled by Complete Species Inventory.

hours per night, resulting in a total effort of 722 hours person. Voucher specimens were killed and fixed according to the usual techniques described by McDiarmid (1994) and deposited in the amphibians collection of Museu Nacional, Universidade Federal do Rio de Janeiro (MNRJ). We also gathered data from specimens previously collected within the PNRJ and deposited in the herpetological collection of MNRJ. All voucher specimens (collected by us or already deposited at MNRJ) are listed in Appendix.
Species richness was estimated by the extrapolation of the accumulation curve through the Jackknife 1 estimator (Burnham \& Overton, 1979) for incidence data, in the software EstimateS Win 9.1.0 (Colwell 2013). Only species recorded during the surveys of the present study were included in the Jackknife 1. Third-party records (Itapotihyla langsdorffii [Duméril \& Bibron, 1841]), species collected close to the limits of the park (Physalaemus marmoratus [Reinhardt \& Lutken, 1862]) or data from herpetological collections (Chthonerpeton 

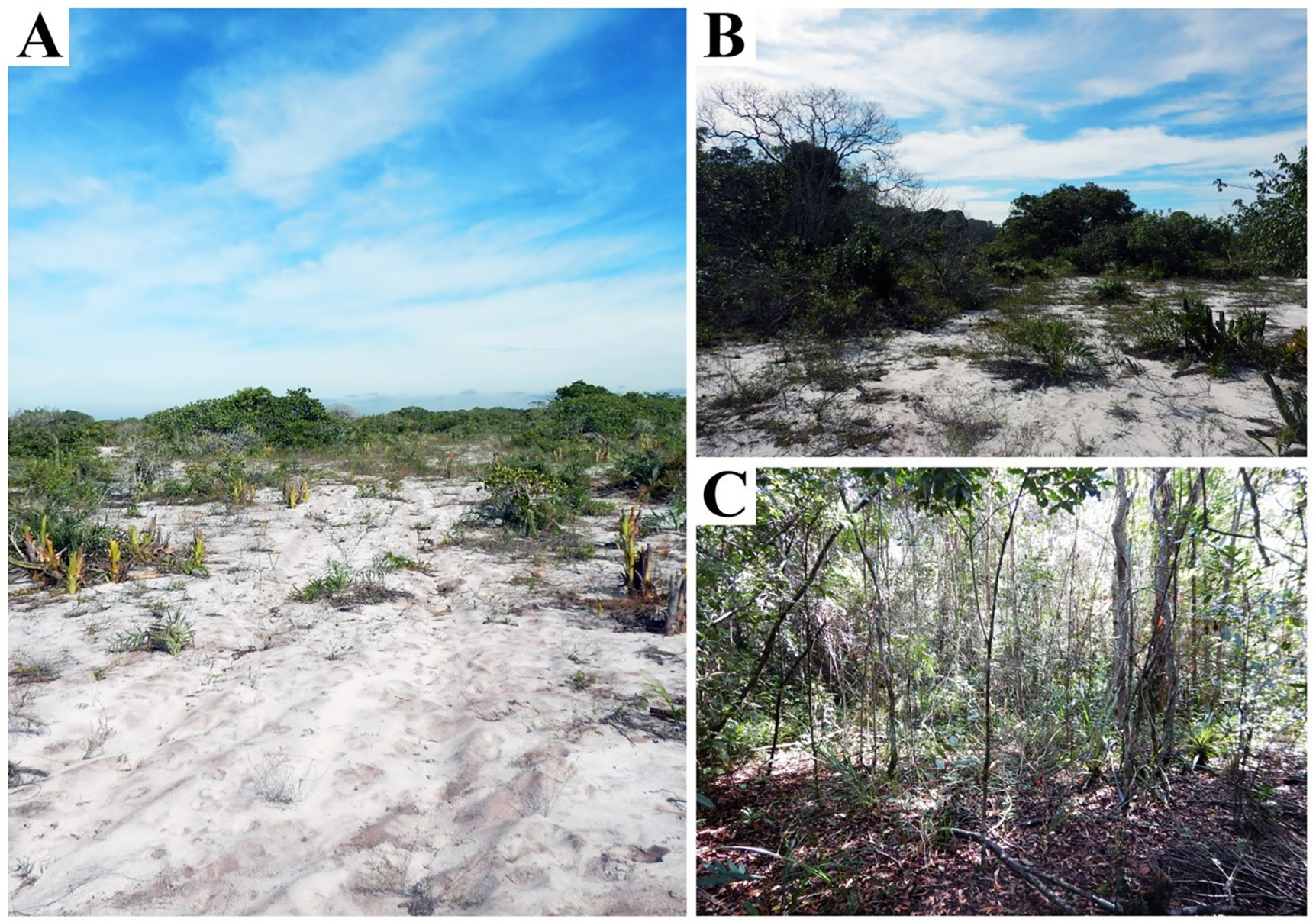

Figure 2. Sampled areas in the Parque Nacional da Restinga de Jurubatiba, state of Rio de Janeiro, southeastern Brazil: A = Shrub Vegetation of Clusia $(\mathrm{SVC}) ; \mathrm{B}=$ Open Shrub of Ericaceae (OSE); C = Dry forest of resting (DFR).

braestrupi Taylor, 1968; Dendropsophus meridianus [Lutz, 1954]) were included in the species list, but were not included in the accumulation curve. Jackknife 1 was used since this analysis takes into account the number of uniques (samples with the only record of a species in the area). The estimated species richness was compared to the total recorded species richness, in order to check the accuracy of the richness estimator and to predict the effort necessary to achieve a richness value much closer to the "real" species richness.

\section{Results}

We recorded a total of 36 amphibian species occurring in the PNRJ area (Table 1): one Gymnophiona (Typhlonectidae) and 35 species of five anuran families: Bufonidae (2 species), Craugastoridae (1), Hylidae (21), Leptodactylidae (8) and Microhylidae (3). The Complete Species Inventory was the most effective survey method, recording 29 from the 36 species found in PNRJ, 21 of them recorded only by this method (Table 1).

One taxa is reported for the first time in the restinga ecosystem: Chthonerpeton braestrupi Taylor, 1968. Moreover, 24 species were recorded for the first time to the PNRJ area. Some of the recorded species present a well-defined distribution pattern within the decribed sampling areas: 25 species were recorded in the phytophysiognomic zone characterized as Shrub Vegetation of Clusia (SVC); 21 were recorded in the Open Shrub of Ericaceae (OSE); and 28 in the Dry Forest Restinga (DFR). Two species (Scinax alter [Lutz, 1973] and S. tymbamirim Nunes, Kwet \& Pombal, 2012) were recorded in all the study sites. However, species as Dendropsophus berthalutzae (Bokermamn, 1962), Dendropsophus cf. haddadi, Stereocyclops parkeri (Wettstein, 1934), Adenomera thomei (Almeida \& Angulo, 2006), and Chiasmocleis lacrimae Peloso, Sturaro, Forlani, Gaucher, Motta \& Wheeler, 2014 were found only in phytophysiognomic zone characterized as Dry Forest Restinga. C. lacrimae, S. parkeri and Physalaemus signifer (Girard, 1853) were recorded only by pitfall traps.

The steep slope in the rarefaction curve occurred until the seventeenth day of sampling, when 29 species were recorded in the PNRJ area. From this day onwards, the rarefaction curve indicated a high tendency to stabilize, with only five new records until the end of the sampling. The species richness was estimated at 34.97 (Jacknife 1 ), a value quite close to the actual number of species registered to PNRJ (Fig. 3).

\section{Discussion}

Previous studies on amphibian composition in restinga habitats were carried out by Silva et al. (1988) in the Restinga da Barra de Maricá, state of Rio de Janeiro. Since then, the number of studies concerning restinga habitats increased significantly. Oliveira \& Rocha (2015) 
Amphibians of Jurubatiba National Park, Brazil

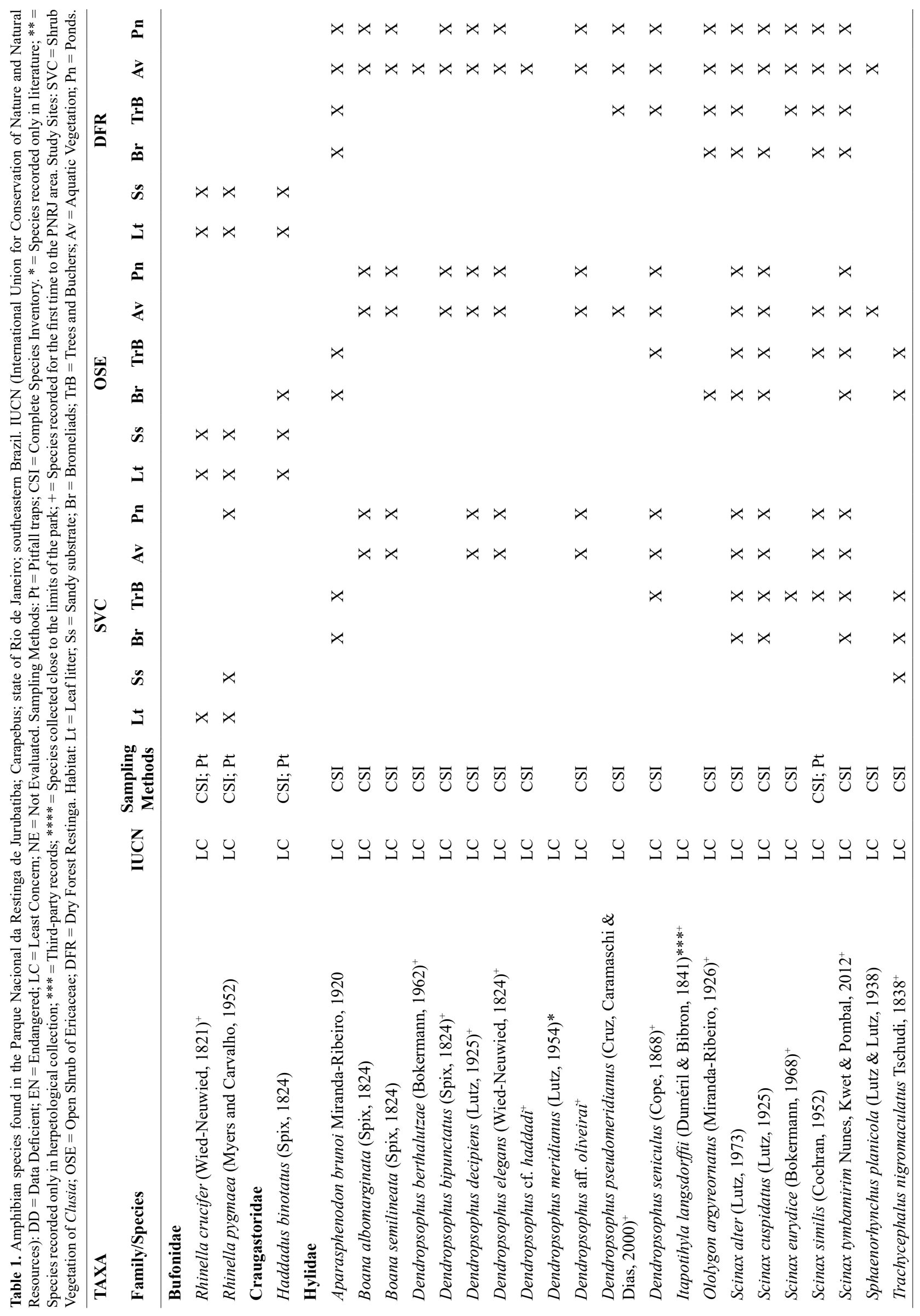


Carmo, L.F. et al.

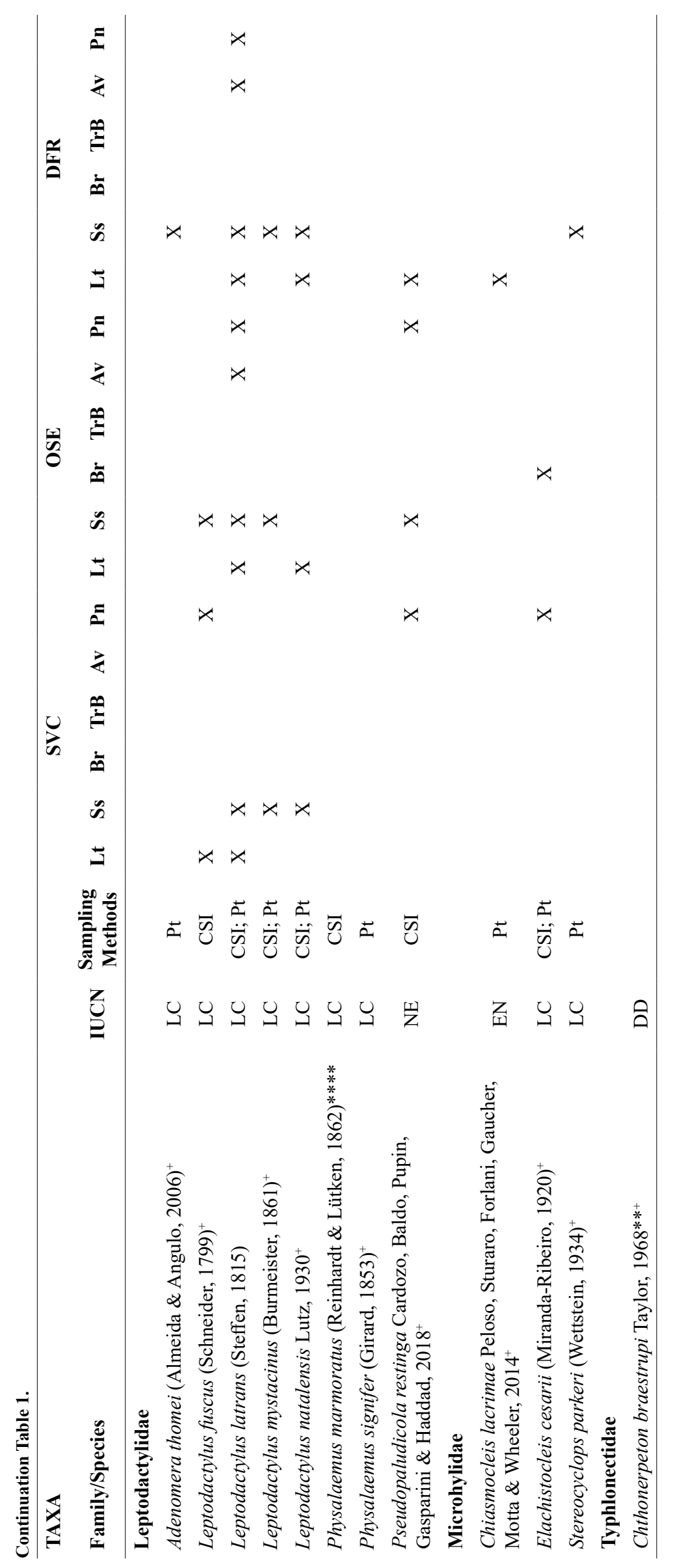




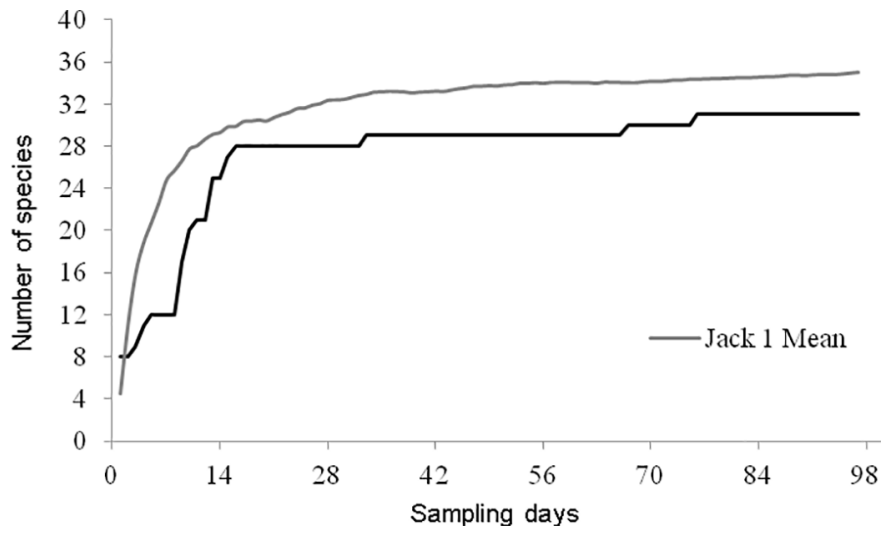

Figure 3. Extrapolation of the accumulation curve through the Jackknife 1 from 1000 randomizations on the order of samplings (grey line) and accumulation curve (black line) for amphibiam species at the Parque Nacional da Restinga de Jurubatiba, state of Rio de Janeiro, southeastern Brazil.

published a review on the anurofauna of the Brazilian sandy coastal plains, recording the occurrence of 145 species at this ecosystem. The 36 species registered for the PNRJ in the present study correspond to $24.8 \%$ of all the amphibian richness found in the ecosystem comprising restingas (Oliveira \& Rocha 2015), standing out as the restinga environment with the highest amphibian species richness recorded. Some other areas of restinga with studied amphibian communities are: Mata de São João, in the state of Bahia, with 34 recorded species (Bastazini et al. 2007); restinga of the municipality of Conde, in the state of Bahia, with 33 species (Gondim-Silva et al. 2016); Parque Natural Municipal de Grumari, in the state of Rio de Janeiro, with 22 species (Telles et al. 2012); Estação Ecológica Juréia-Itatins, in the state of São Paulo, with 20 species (Narvaes et al. 2009); Parque Estadual da Ilha do Cardoso, in the state of São Paulo, with 17 species (Vilela et al. 2011); Baixada do Maciambu, in the state of Santa Catarina, with 15 species (Wachlevski \& Rocha 2010); Restinga da Barra de Maricá, state of Rio de Janeiro, with 14 recorded species (Silva et al. 1988); Praia das Neves, in the state of Espírito Santo, with 13 species (Rocha et al. 2008), and Marambaia, in the state of Rio de Janeiro, with 12 species (Silva et al. 2008).

Although PNRJ is the Restinga with the second most studied anuran community (Oliveira \& Rocha, 2015), the present study registered 24 species not recorded to the region (Table 1). This result reinforces the importance of long-term studies for accurate knowledge of the biodiversity. The family Hylidae is the most representative, corresponding to $60 \%$ of the total anuran species recorded for the PNRJ ( 21 of 35). The greater representativeness of this family reinforces the pattern found in all ecosystems studied within the Atlantic Forest Biome (e.g., Heyer et al. 1990; Duellman 1999; Canelas \& Bertoluci 2007; Dias et al. 2014; Garey et al. 2014).

Some of the reported species (Fig. 4-5), such as Scinax tymbamirim and $S$. alter, show a vast spatial distribution within of the PNRJ and were not recorded for only two of the sampled microhabitats: leaf litter (Lt) and sandy substrate (Ss) (Table 1). These species present plasticity in relation to environmental changes, being able to inhabit different ecosystems, a favorable aspect for species that live in degraded and unstable environments (Vasconcelos et al. 2018). Others species such as Dendropsophus berthalutzae, D. cf. haddadi, Stereocyclops parkeri, Adenomera thomei, and Chiasmocleis lacrimae were found in only one microhabitat each, all in the dry forest restinga study site (Table 1).

One of the 36 species registered, Chiasmocleis lacrimae, is categorized as "Endangered" (EN) by the IUCN Red List (Pimenta $\&$ Peixoto 2004), reinforcing the importance of the restingas as conservation priority areas. One of the anurans registered in PNRJ was recently described: Pseudopaludicola restinga Cardozo, Baldo, Pupin, Gasparini \& Haddad, 2018, compromising adequate avaliation of its conservational status. In the present study, we report the first record of this taxon outside the state of Espírito Santo, Brazil. This record represents an increase of its known geographic distribution of approximately $140 \mathrm{~km}$ to south from its nearest locality (Restinga de Praia das Neves, municipality of Presidente Kennedy [2 $1^{\circ} 14^{\prime} 41.53$ ”'S; 4058'45.80"W; $6 \mathrm{~m}$ asl], state of Espírito Santo, Brazil; according to Cardozo et al. 2018). The only species representative of the order Gymnophiona, Chthonerpeton braestrupi, is categorized in the IUCN Red Book as "Data Deficient" (DD) concerning its distribution, as well as taxonomy and ecological parameters (Wilkinson et al. 2004). The similarity with Chthonerpeton indistinctum (Reinhardt \& Lütken, 1862), a relatively close and better known species (Maneyro \& Langone 2001; Canavero et al. 2010), which is affected by urban occupation in coastal and agricultural areas, corroborates that these anthropic impacts may also affect populations of $C$. braestrupi in the Brazilian coastal zone. The other 33 species are listed and considered as "Least Concern" (LC) according to the IUCN Red Book (IUCN 2018) (Table 1).

None of the species recorded to the PNRJ is endemic to the park, reinforcing the pattern already described for the other restingas. Only five anuran species are known as endemic to this environment (Rocha et al. 2005; Peloso et al. 2012): Ololygon agilis (Cruz \& Peixoto, 1983), Ololygon littoreus Peixoto, 1988, Xenohyla truncata (Izecksohn, 1959), Leptodactylus marambaiae Izecksohn, 1976, and Melanophryniscus setiba Peloso, Faivovich, Grant, Gasparini, \& Haddad, 2012. Until recently, Rhinella pygmaea (Myers \& Carvalho, 1952) was considered endemic to the restinga habitats. However, Silveira et al. (2009) recorded the species at semideciduous seasonal forest formations in the states of Rio de Janeiro and Espírito Santo. Considering that the biodiversity of the fragments of the sandy coastal environments in the state of Rio de Janeiro is poorly known, the present study provided a more detailed knowledge about different aspects of the biodiversity in the PNRJ, contributing to the preservation of this threatened ecosystem.

Currently, the PNRJ is the only area within the 72 Brazilian national parks distributed throughout the country to enclose this ecosystem (Brasil 2016). In addition, few restinga areas correspond to other categories of conservation units and only a few receive integral protection (Rocha et al. 2004b). Therefore, more studies are needed to subsidize the maintenance and implementation of conservation policies in other areas of restinga in Brazil. The PNRJ has a long tradition regarding conservation initiatives, including protection of threatened species and the socio-environmental development of sustainable alternatives for those who live from the resources offered by this ecosystem (Rocha et al. 2004b; Esteves 2011; Silva et al. 2012). Many of these measures were supported by science-based conservation planning (see Esteves 2011). According to Margules \& Pressey (2000), 
Carmo, L.F. et al.
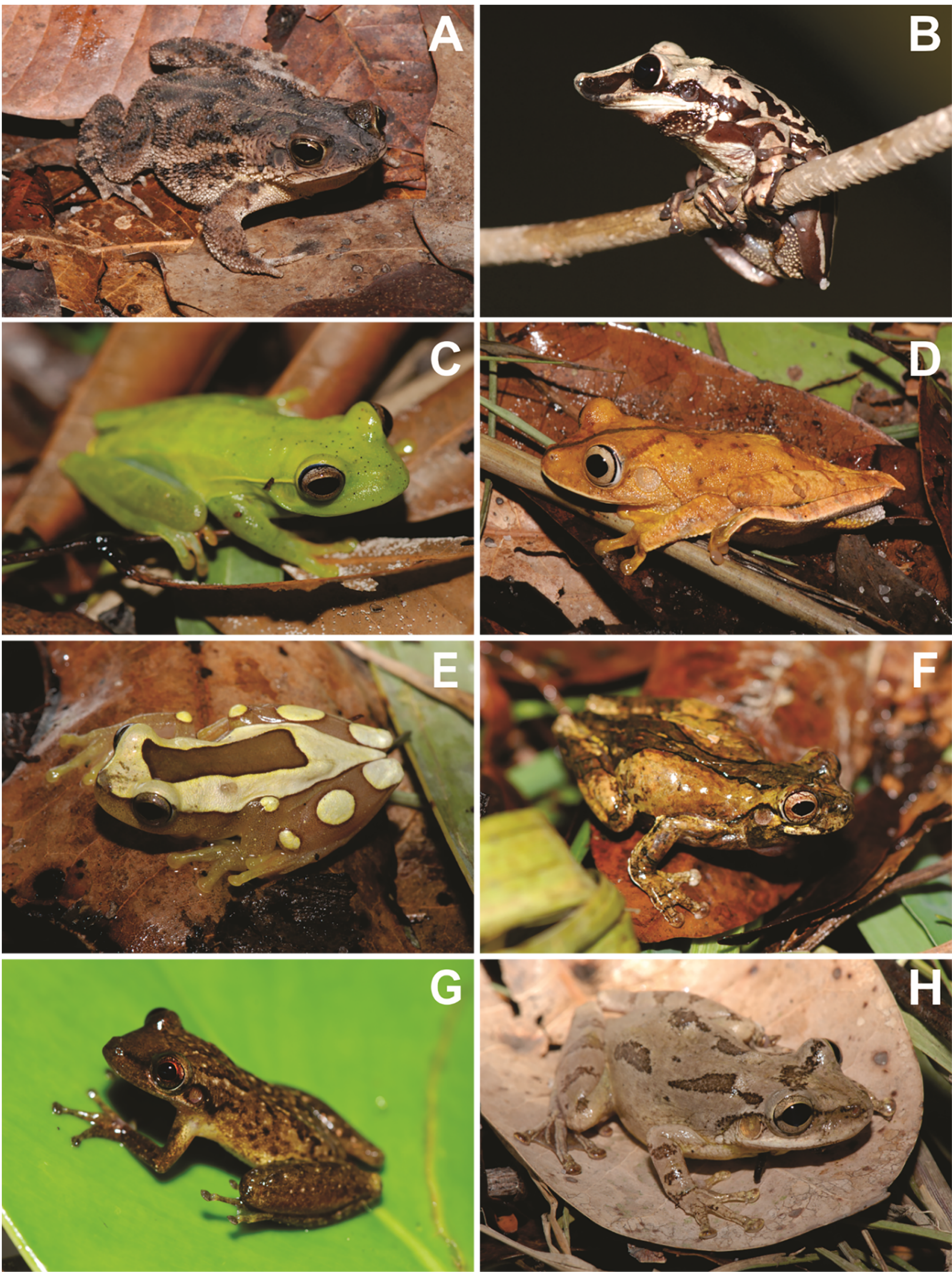

Figure 4. Some anurans from Parque Nacional da Restinga de Jurubatiba, state of Rio de Janeiro, southeastern Brazil: A) Rhinella pygmaea; B) Aparasphenodon brunoi; C) Boana albomarginata; D) Boana semilineata; E) Dendropsophus elegans; F) Dendropsophus marmoratus; G) Scinax eurydice; H) Scinax cuspidatus. Photos from MNFoto/Setor de Herpetologia, Museu Nacional, UFRJ. 

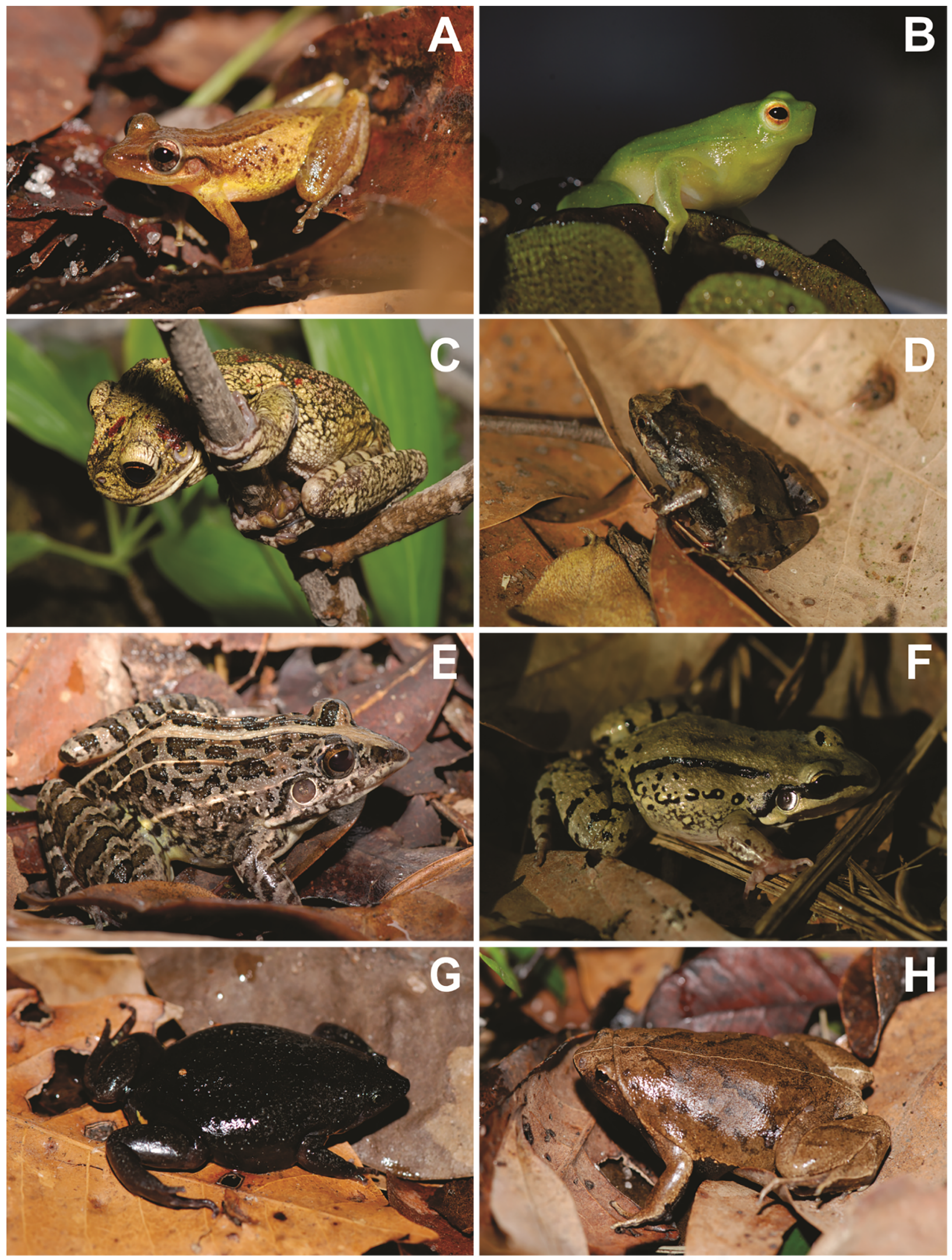

Figure 5. Some anurans from Parque Nacional da Restinga de Jurubatiba, state of Rio de Janeiro, southeastern Brazil: A) Scinax tymbamirim; B) Sphaenorhynchus planicola; C) Trachycephalus nigromaculatus; D) Physalaemus signifer; E) Leptodactylus fuscus; F) Leptodactylus mystacinus; G) Elachistocleis cesarii; H) Stereocyclops parkeri. Photos from MNFoto/Setor de Herpetologia, Museu Nacional, UFRJ. 
one can only preserve what is known, and the first stage to conserve biodiversity is to describe, to map and to measure it. In the last years, several studies pointed to the occurrence of population declines in different parts of the world (Stuart et al. 2004), mostly caused by the destruction of natural areas. The PNRJ is a region of special relevance for the protection of the biodiversity from the coastal region of state of Rio de Janeiro. According to Rocha et al. (2005), the areas between the restingas of Maricá and Jurubatiba are of great importance for the maintenance of the biodiversity of local terrestrial vertebrates. Rocha et al. (2007) identified 14 sites of degradation in restinga areas and estimate that 1,257 hectares of the PNRJ are degraded, mostly due to the removal of native flora communities for the establishment of grazing areas for livestock and urban occupation. All these factors tend to cause significant impacts on the faunal communities present in the park. It is well known that amphibians comprise the most threatened vertebrate group and this, coupled with the current dynamics of changes in this ecosystem, will lead to the extinction of many species, some of them even before being described (Howard \& Bickford 2014).

In addition, the PNRJ is an important area for the protection of different taxa, harboring some of the species that are endemic to the restingas ecosystem, such as the lizard Glaucomastix littoralis (Rocha, Bamberg Araújo \& Vrcibradic, 2000) (Squamata: Teiidae) (Cosendey et al. 2016), the rodent Cerradomys goytaca Tavares, Pessôa \& Gonçalves, 2011 (Rodentia: Cricetidae) (Lemos \& Gonçalves 2015), and the fish Atlantirivulus jurubatibensis (Costa, 2008) (Cyprinodontiformes: Rivulidae) (Costa, 2008).

In conclusion, the detailed knowledge about the diverse aspects of the biodiversity existing in the PNRJ, provide means to subsidize the maintenance and implementation of conservation policies to other areas of restinga in Brazil. Ecosystems with high biodiversity, such as the Atlantic Forest, demand a continuous expansion of protected areas in the most diverse categories of Conservation Units according to the federal legislation. The Atlantic Forest suffered severe deforestation as a consequence of its geographic location, originally occupying most of the coastal strip of the Brazilian territory, a place that sheltered and consolidated the permanence of $80 \%$ of the Brazilian population and the infrastructure for its development (Rocha et al. 2004b). Only about $11 \%$ of this biome remains preserved in Brazil, with very few native forested fragments, while the rest of the fragments consist of secondary forest (Ribeiro et al. 2009). It is necessary to expand these protected areas, as well as their interconnections to the formation of biological corridors, essential for maintaining and expanding the existing biodiversity bases.

\section{Supplementary material}

The following online material is available for this article: Appendix

\section{Acknowledgements}

We thank Marcos Bilate and Rodrigo de Oliveira Lula Sales for review and suggestions. We are grateful to Aldo Caccavo; Bruna Pagliani; Bruno Miranda; Carina Azevedo; Carolina Silva-Barros; Cristiane Régis; Daniel Almada; Hudson Lemos; Jéssica Erasmi; Jessica Fratani; João Marcelo; Leonardo Lopes; Natália Souto; Natasha
Radsack; Pablo Gonçalves; Pedro C. Prado; Pedro H. Cabral; Theo Aroeira; Vagner dos Santos; Macaé Fora de Estrada (MFE); PARNA de Jurubatiba/ICMBio staff for fieldwork help. We are especially grateful to Ana C. Petry and Pablo Gonçalves for logistical support. This project is part of the program Pesquisas Ecológicas de Longa Duração (PELD): Mudanças Climáticas Globais e o Funcionamento dos Ecossistemas Costeiros da Bacia de Campos: uma perspectiva espaço-temporal (Long Term Ecological Research program: Global Climate Changes and the Functioning of Coastal Ecosystems in the Bacia de Campos: A space-time perspective), iniciated in August 2013 and subsidized by Conselho Nacional de Desenvolvimento Científico e Tecnológico (CNPq). In addition, it also integrates the program: Levantamento e Aspectos Biológicos da Herpetofauna do Parque Nacional da Restinga de Jurubatiba, RJ, Brasil, subsidized by Fundação de Amparo a Pesquisa do Estado do Rio de Janeiro (FAPERJ). Both promoting institutions were extremely important for the development of this research. The specimens were collected under permit \#38378-11, granted by the Instituto Chico Mendes de Conservação da Biodiversidade (ICMBio).

\section{Author Contributions}

Luiz Fernando Carmo: Substantial contribution in the concept and design of the study; contribution to data collection; contribution to data analysis and interpretation; contribution to manuscript preparation; contribution to critical revision, adding intelectual content.

Ingrid Ribeiro Miguel: Substantial contribution in the concept and design of the study; contribution to data collection; contribution to manuscript preparation; contribution to critical revision, adding intelectual content.

Pedro H. Pinna: Substantial contribution in the concept and design of the study; contribution to data collection; contribution to manuscript preparation; contribution to critical revision, adding intelectual content.

Daniel Silva Fernandes: Substantial contribution in the concept and design of the study; contribution to data collection; contribution to manuscript preparation; contribution to critical revision, adding intelectual content.

Manoela Woitovicz-Cardoso: Substantial contribution in the concept and design of the study; contribution to data collection; contribution to data analysis and interpretation; contribution to manuscript preparation; contribution to critical revision, adding intelectual content.

\section{Conflicts of interest}

The authors declare that they have no conflict of interest related to the publication of this manuscript.

\section{References}

ASSUMPÇÃO, J. \& NASCIMENTO, M.T. 2000. Estrutura e composição floristica de quatro formações vegetais de restinga no complexo lagunar Grussai/Iquipari, São João da Barra, RJ, Brasil. Acta Botanica Brasilica 14(3): 301-315

ARAUJO, D.S.D., SCARANO, F.R., KURTZ, B.C., ZALUAR H, L.T., MONTEZUMA, R.C.M. \& OLIVEIRA, R.C. 1998. Comunidades vegetais do Parque Nacional de Restinga de Jurubatiba. In Ecologia das lagoas costeiras do Parque Nacional da Restinga de Jurubatiba e do município de Macaé (F.A. Esteves, ed.). Rio de Janeiro: NUPEM-UFRJ, p.37-62. 
BASTAZINI, C.V., MUNDURUCA, J.F.V., ROCHA, P.L.B. \& NAPOLI, M.F. 2007. Which environmental variables better explain changes in anuran community composition? A case study in the restinga of Mata de São João, Bahia, Brazil. Herpetologica 63(4): 459-471.

BRASIL. Instituto Chico Mendes de Conservação da Biodiversidade - ICMBio. Ministério do Meio Ambiente (MMA). 2016. Parques Nacionais do Brasil. Downloaded on 31 January 2018. p.1-20.

BURNHAM, K.P. \& OVERTON, W.S. 1979. Robust estimation of population size when capture probabilities vary among animals. Ecology 60(5): 927936.

CANAVERO, A., CARREIRA, S., LANGONE, J.A., ACHAVAL, F., BORTEIRO, C., CAMARGO, A., ROSA, I., ESTRADES, A., FALLABRINO, A., KOLENC, F., LÓPEZ-MENDILAHARSU, M.M., MANEYRO, R., MENEGHEL, M., NUÑEZ, D., PRIGIONI, C.C. \& ZIEGLER, L. 2010. Conservation status assessment of the amphibians and reptiles of Uruguay. Iheringia, Série Zoologia 100(1): 5-12.

CANELAS, M.A.S. \& BERTOLUCI, J. 2007. Anurans of the Serra do Caraça, southeastern Brazil: species composition and phenological patterns of calling activity. Iheringia, Série Zoologia 97(1): 21-26.

CARDOZO, D.E., BALDO, D., PUPIN, N., GASPARINI, J.L. \& HADDAD, C.F.B. 2018. A new species of Pseudopaludicola (Anura, Leiuperinae) from Espírito Santo, Brazil. PeerJ 6:e4766.

CECHIN, S.Z. \& MARTINS, M. 2000. Eficiência de armadilhas de queda (pitfall traps) em amostragem de anfíbios e répteis no Brasil. Revista Brasileira de Zoologia 17(3): 729-740.

COGLIATTI-CARVALHO, L., NUNES DE FREITAS, A.F., ROCHA, C.F.D. \& VAN SLUYS, M. 2001. Variação na estrutura e na composição de Bromeliaceae em cinco zonas de restinga no Parque Nacional da Restinga de Jurubatiba, Macaé, RJ. Revista Brasileira de Botânica 24(1): 1-9.

COLWELL, R.K. 2013. EstimateS: Statistical estimation of species richness and shared species from samples. Version 9. Persistent URL: <purl.oclc. org/estimates>.

COSENDEY, B.N., ROCHA, C.F.D. \& MENEZES, V.A. 2016. Population density and conservation status of the Teiid lizard Cnemidophorus littoralis, an endangered species endemic to the sandy coastal plains (restinga habitats) of Rio de Janeiro state, Brazil. Journal of Coastal Conservation 20(2). DOI 10.1007/s11852-016-0421-4.

COSTA, W.J.E.M. 2008. Rivulus jurubatibensis, a new aplocheiloid killifish from the southeastern Brazilian coastal plains (Cyprinodontiformes: Rivulidae). Ichthyological Exploration Freshwaters 19(2): 135-140.

CRUZ, C.A.G. \& PEIXOTO, L. 1983. Uma nova especie de Hyla do estado do Espirito Santo, Brasil (Amphibia, Anura, Hylidae). Revista Brasileira de Biologia 42: 721-724.

DEAN, W. 1997. With Broadax and Firebrand: The Destruction of the Brazilian Atlantic Forest. University of California Press, pp.504.

DIAS, I.R., MEDEIROS, T.T., NOVA, M.F.V. \& SOLÉ, M. 2014. Amphibians of Serra Bonita, southern Bahia: a new hotpoint within Brazil's Atlantic Forest hotspot. ZooKeys 449: 105-130.

DUELLMAN, W.E. 1999. Patterns of distribution of amphibians: A Global Perspective. The Johns Hopkins University Press, Baltimore.

ESTEVES F.A. \& LACERDA L.D. 2000. Ecologia de restingas e lagoas costeiras. Computer \& Publish Editoração Gráfica. Núcleo de Pesquisas Ecológicas de Macaé (NUPEM/UFRJ), pp. 394.

ESTEVES, F.A. 2011. Do Índio Goitacá à economia do petróleo: Uma viagem pela história e ecologia da maior restinga protegida do Brasil. Ed. Essentia, Campos dos Goytacazes, RJ, pp. 232.

FALKENBERG, D.B. 1999. Aspectos da flora e vegetação secundária da restinga de Santa Catarina, Sul do Brasil. INSULA Revista de Botânica 28: 1-30.

FISHER, M.C., HENK, D.A., BRIGGS, C.J., BROWNSTEIN, J.S., MADOFF, L.C., MCCRAW, S.L. \& GURR, S.J. 2012. Emerging fungal threats to animal, plant and ecosystem health. Nature 484: 186-194.

FREIRE, M.S.B.1990. Levantamento florístico do Parque Estadual das Dunas de Natal. Acta Botânica Brasílica, 4(2): 41-59.
FROST, D.R. 2018. Amphibian Species of the World: an Online Reference. Version 6.0. American Museum of Natural History, New York, USA Available online at: http://research.amnh.org/vz/herpetology/amphibia/. (last access on 07/04/2018).

GAREY, M.V., PROVETE, D.B., MARTINS, I.A., HADDAD, C.F.B. \& ROSSA-FERES, D.C. 2014. Anurans from the Serra da Bocaina National Park and surrounding buffer area, southeastern Brazil. Check List: Jounal of species list and distribuition 10(2): 308-316.

GONDIM-SILVA, F.A.T., ANDRADE, A.R.S., ABREU, R.O., NASCIMENTO, J.S., CORREAA, G.P., MENEZES, L., TREVISAN, C.C., CAMARGO, S.S. \& NAPOLI, M. F. 2016. Composition and diversity of anurans in the Restinga of the Conde municipality, northern coast of the state of Bahia, Northeastern Brazil. Biota Neotropica 16(3): e20160157. http://www. biotaneotropica.org.br/v16n3/pt/abstract?article + bn01016032016. (last accessed on: 25/08/2017).

HADDAD, C.F.B. \& PRADO C.P.A. 2005. Reproductive modes in frogs and their unexpected diversity in the Atlantic Forest of Brazil. BioScience 55(3): 207-217.

HADDAD, C.F.B., TOLEDO, L.F., PRADO, C.P.A., LOEBMANN, D., GASPARINI, J L. \& SAZIMA, I. 2013. Guia dos anfíbios da Mata Atlântica - Diversidade e Biologia. Anolis Books Editora, pp. 544.

HENRIQUES, R.P.B., ARAÚJO, D.S.D. \& HAY, J.D. 1986. Descrição e classificação dos tipos de vegetação da restinga de Carapebus, Rio de Janeiro. Revista Brasileira de Botânica 9: 173-189.

HEYER, W.R., RAND, A.S., CRUZ, C.A.G., PEIXOTO, O.L. \& NELSON, C.E. 1990. Frogs of Boracéia. Arquivos de Zoologia 31(4): 231-410.

HOWARD, S.D. \& BICKFORD, D.P. 2014. Amphibians over the edge: silent extinction risk of Data Deficient species. Diversity and Distributions 20(7): 837-846.

IUCN (INTERNATIONAL UNION FOR CONSERVATION OF NATURE). 2018. IUCN Red List of threatened species. Version 2018.2. http://www. iucnredlist.org/ (last access on 30/11/2018).

IZECKSOHN, E. 1959. Uma nova espécie de "Hylidae" da Baixada Fluminense, Estado do Rio de Janeiro, Brasil. Revista Brasileira de Biologia 19: 259-264.

IZECKSOHN, E. 1976. Uma nova espécie de Leptodactylus do Estado do Rio de Janeiro, Brasil (Amphibia, Anura, Leptodactylidae). Revista Brasileira de Biologia 36: 527-530.

JENKINSON, T.S., BETANCOURT ROMÁN, C.M., LAMBERTINI, C., VALENCIA-AGUILAR, A., RODRIGUEZ, D., NUNES-DE-ALMEIDA, C.H.L., RUGGERI, J., BELASEN A.M., DA SILVA-LEITE, D., ZAMUDIO, K.R., LONGCORE, J.E., TOLEDO, F.L. \& JAMES, T.Y. 2016. Amphibian-killing chytrid in Brazil comprises both locally endemic and globally expanding populations. Molecular Ecology 25: 2978-2996.

LACERDA, L.D., ARAUJO, D.S.D. \& MACIEL, N.C. 1993. Dry coastal ecosystems of the tropical Brazilian coastal in dry coastal-ecosystems: Africa, Asia, Oceania (E. Van der Maarel, ed.). Elsevier, Amsterdam, pp. 477-493.

LEMOS, H.M. \& GONÇALVES, P.R. 2015. DINÂMICA POPULACIONAL DE CERRADOMYS GOYTACA TAVARES, PESSÔA \& GONÇALVES, 2011 (RODENTIA: CRICETIDAE), Uma espécie endêmica de restingas. Oecologia Australis 19(1): 195-214.

LOYOLA, R.D., LEMES, P., BRUM, F.T., PROVETE, D.B. \& DUARTE, L.D.S. 2014. Clade-specific consequences of climate change to amphibians in Atlantic Forest protected areas. Ecography 37: 65-2.

MANEYRO, R. \& LANGONE, J.A. 2001. Categorización de los anfíbios del Uruguay. Cuadernos de Herpetología 15 (2): 107-118.

MARGULES, C.R \& PRESSEY R.L. 2000. Systematic conservation planning. Nature 405: 243-253.

MCDIARMID, R.W. 1994. Preparing amphibians as scientific specimens. In Measuring and monitoring biological diversity: standard methods for amphibians (Heyer W.R. et al., eds.). Washington, D.C. Smithsonian Institution Press, pp. 289-297.

MYERS, N., MITTERMEIER, R.A., MITTERMEIER, C.G., FONSECA, G.A.B. \& KENT, J. 2000. Biodiversity hotspots for conservation priorities. Nature 403: 853-858. 
NARVAES, P., BERTOLUCI, J. \& RODRIGUES, M.T. 2009. Composição, uso de hábitat e estações reprodutivas das espécies de anuros da floresta de restinga da Estação Ecológica Juréia-Itatins, sudeste do Brasil. Biota Neotropica 9(2): http://www.biotaneotropica.org.br/v9n2/pt/ abstract?article+bn02009022009. (last accessed on: 30/09/2017).

OLIVEIRA, J.C.F. \& ROCHA, C.F.D. 2015. Journal of coastal conservation: a review on the anurofauna of Brazil's sandy coastal plains. How much do we know about it?. Journal of Coastal Conservation 19: 35-49.

OLIVEIRA, J.C.F., WINCK, G.R., PEREIRA-RIBEIRO, J. \& ROCHA, C.F.D. 2017. Local Environmental Factors Influence the Structure of Frog Communities on the Sandy Coastal Plains of Southeastern Brazil. Herpetologica 73(4): 307-312.

PEIXOTO, O.L. 1988. Sobre o "status" taxonômico de Hyla catharinae alcatraz B. Lutz 1973, com a descrição de uma nova espécie para o grupo perpusilla (Amphibia, Anura, Hylidae). Acta Biologica Leopoldensia. 10: 253-267.

PEIXOTO, O.L. 1995. Associação de anuros a bromeliáceas na Mata Atlântica. Revista Universidade Rural, Serie: Ciências Da Vida 17(2): 75-83.

PELOSO, P.L.V., FAIVOVICH, J., GRANT, T., GASPARINI, J.L. \& HADDAD, C.F.B. 2012. An extraordinary new species of Melanophryniscus (Anura, Bufonidae) from southeastern Brazil. American Museum Novitiates 3762:1-32.

PIMENTA, B. \& PEIXOTO, O.L. 2004. Chiasmocleis lacrimae (errata version published in 2015). The IUCN Red List of Threatened Species: e.T57753A85993475. http://dx.doi.org/10.2305/IUCN.UK.2004.RLTS. T57753A11680689.en. (last access on 18/01/2018)

RIBEIRO, M.C., METZGER, J.P., MARTENSEN, A.C., PONZONI, F.J. \& HIROTA, M.M. 2009. The Brazilian Atlantic Forest: how much is left, and how is the remaining forest distributed? Implications for conservation. Biological Conservation 142:1141-1153.

ROCHA, C.F.D., VAN SLUYS, M., HATANO, F.H., BOQUIMPANI-FREITAS, L., MARRA, R.V. \& MARQUES, R.V. 2004a. Relative efficiency of anuran sampling methods in a restinga habitat (Jurubatiba, Rio de Janeiro, Brazil). Brazilian Journal of Biology, 64 (4): 879-884.

ROCHA, C.F D., BERGALLO H.G., ALVES, M.A.S. \& VAN SLUYS, M. 2004b. A Restinga de Jurubatiba e a conservação dos ambientes de restinga do Estado do Rio de Janeiro. In Pesquisas de Longa Duração na Restinga de Jurubatiba: Ecologia, História Natural e Conservação (C.F.D. Rocha; F.A. Esteves \& F.R. Scarano, eds). Rima Editora, São Carlos 1: 341-352.

ROCHA, C.F.D., VAN SLUYS, M., BERGALLO, H.G. \& ALVES, M.A.S. 2005. Endemic and threatened tetrapods in the restingas of the biodiversity corridors of Serra do Mar and of the Central da Mata Atlântica in eastern Brazil. Brazilian Journal of Biology 65(1):159-168.

ROCHA, C.F.D., BERGALLO, H.G., VAN SLUYS, M., ALVEZ, M.A.S. \& JAMEL, C.E. 2007. Os remanescentes dos habitats de restinga na Floresta Atlântica do estado do Rio de Janeiro, Brasil: perda de habitat e risco de desaparecimento. Brazilian Journal of Biology 67(2): 263-273.

ROCHA, C.F.D., HATANO, F.H., VRCIBRADIC, D. \& VAN SLUYS, M. 2008. Frog species richness, composition and $\beta$-diversity in coastal Brazilian restinga habitats. Brazilian Journal of Biology 68(1): 101-107.

SCARANO, F.R. 2002. Structure, function and floristic relationships of plant communities in stressful habitats marginal to the Brazilian Atlantic Rainforest. Annals of Botany 90: 517-524.

SCHINEIDER, J.A.P. \& TEIXEIRA R.L. 2001. Relacionamento entre anfíbios anuros e bromélias da Restinga de Regência, Linhares, Espirito Santo, Brasil. Iheringia, Série Zoologia, Porto Alegre 91: 41-48.

SCOTT JR., NORMAN, J. 2001. Técnicas estándar para inventarios y monitoreos. Inventario completo de especies. p. 73-80. In Medición y monitoreo de la diversidad biológica. Métodos estandarizados para anfibios. (W.R. Heyer, M.A. Donnelly; R.W. McDiarmid; L.A.C. Hayek \& M.S. Foster, eds). Editorial Universitaria de la Patagonia, Comodoro Rivadavia, Argentina, pp. 349.
SEGALLA, M.V., CARAMASCHI, U., CRUZ, C.A.G., GRANT, T., HADDAD, C.F.B., GARCIA, P.C.A., BERNECK, B.V.M. \& LANGONE, J.A. 2016. Brazilian amphibians: list of species. Herpetologia Brasileira 5: 34-46.

SILVA, H.R., BRITO-PEREIRA M.C., CARAMASCHI, U. \& CERQUEIRA, R. 1988. Anfíbios anuros da Restinga de Maricá: levantamento e observações preliminares sobre a atividade reprodutiva das espécies registradas. Anais do Seminário Regional de Ecologia 6: 295-306.

SILVA, H.R., CARVALHO, A.L.G. \& BITTENCOURT-SILVA, G.B. 2008. Frogs of Marambaia: a naturally isolated restinga and Atlantic Forest remnant of southeastern Brazil. Biota Neotropica 8(4): 167-174. http:// www.biotaneotropica.org.br/v8n4/pt/abstract?article+bn01808042008. (last accessed on: 15/07/2017).

SILVA, D.P., GOMES, I.A.M. \& CRUZ, M.A.L. 2012. Vegetação de restinga: aspectos do impacto provocado pelo desenvolvimento sócioeconômico da região norte-fluminense e alternativas para sua valorização. InterSciencePlace 23(1):71-83.

SILVEIRA, A.L., SALLES, R.O.L. \& PONTES, R.C. 2009. Amphibia, Anura, Bufonidae, Rhinella pygmaea: Distribution extension and geographic distribution map. Check List 5(3): 749-752.

STUART, S.N., CHANSON, J.S., COX, N.A., YOUNG, B.E., RODRÍGUEZ, A.S.L., FISHMAN, D.L. \& WALLER, R.W. 2004. Status and trends of amphibian declines and extinctions worldwide. Science 306: 1783-1786.

TABARELLI, M., AGUIAR, A.V., RIBEIRO, M.C. \& METZGER J.P. 2010. Prospects for biodiversity conservation in the Atlantic Forest: Lessons from aging human-modified landscapes. Biological Conservation 143(10): 2328-2340.

TEIXEIRA, R.L., SCHINEIDER, J.A.P. \& ALMEIDA, G.I. 2002. The occurrence of amphibians in bromeliads from southeastern Brazilian resting habitat, with special reference to Aparasphenodon brunoi (ANURA, HYLIDAE). Brazilian Journal of Biology 62(2): 263-268.

TELLES, S.B.S., MENEZES, V.A., MAIA-CARNEIRO, T., DORIGO, T.A., WINCK, G.R. \& ROCHA, C.F.D. 2012. Anurans from the "Restinga" of Parque Natural Municipal de Grumari, state of Rio de Janeiro, southeastern Brazil.Check List 8(6): 1267-1273.

VAN SLUYS, M., ROCHA, C.F.D., HATANO, F.H., BOQUIMPANI-FREITAS, L. \& MARRA, R.V. (2004): Anfíbios da Restinga de Jurubatiba: composição e história natural. In Pesquisas de longa duração na restinga de Jurubatiba: ecologia, história natural e conservação (C.F.D. Rocha, F.A. Esteves \& F.R. Scarano, eds.). - RiMa, São Carlos, SP, p.165-318.

VASCONCELOS, T.S., DOS SANTOS, T.G., HADDAD, C.F.B. \& ROSSAFERES, D.C. 2010. Climatic variables and altitude as predictors of anuran species richness and number of reproductive modes in Brazil. Journal of Tropical 26 (4): 423-432.

VASCONCELOS T.S., NASCIMENTO, B.T.M. \& PRADO V.H.M. 2018. Expected impacts of climate change threaten the anuran diversity in the Brazilian hotspots. Ecology and Evolution 8: 7894-7906. https://doi. org/10.1002/ece3.4357.

VILELA, V.M.F.N., BRASSALOTI, R.A. \& BERTOLUCI, J. 2011. Anuran fauna of the restinga forest of the Parque Estadual da Ilha do Cardoso, Southeastern Brazil: species composition and breeding site utilization. Biota Neotropica 11(1) 83-93

WACHLEVSKI, M. \& ROCHA, C.F.D. 2010. Amphibia, Anura, restinga of Baixada do Maciambu, municipality of Palhoça, state of Santa Catarina, southern Brazil. - Check List 6: 602-604.

WILKINSON, M., MEASEY, J., SILVANO, D. \& CRUZ, C.A.G. 2004. Chthonerpeton braestrupi. The IUCN Red List of Threatened Species. e.T59535A11960054. http://dx.doi.org/10.2305/IUCN.UK.2004.RLTS. T59535A11960054.en. (last accessed on: 18/01/2017). 